\title{
PENERAPAN TEKNIK JIGSAW UNTUK MENINGKATKAN KETERAMPILAN MEMAHAMI BACAAN BAHASA INGGRIS DENGAN MEMPERHATIKAN SIKAP BERBAHASA SISWA
}

\author{
Supeno $^{1}$, Imam Suseno ${ }^{2}$ \\ Fakultas Bahasa dan Seni, Universitas Indrprasta PGRI \\ ${ }^{1}$ supenofbs@gmail.com, ${ }^{2}$ susenoblr@gmail.com
}

\begin{abstract}
Abstrak
Peningkatan keterampilan memahami bacaan bahasa Inggris dengan menerapkan teknik pembelajaran JIGSAW merupakan bagian dari upaya memperbaiki situasi dan proses pembelajaran di kelas. Teknik pembelajaran JIGSAW dengan memperhatikan beberapa aspek: pembentukan kelompok diskusi, penentuan jumlah anggota dalam satu kelompok, jumlah siswa yang mewakili sebagai kelompok ahli, dan cara evaluasi untuk menilai efektivitas diskusi serta upaya meningkatkan sikap berbahasa siswa. Penelitian ini termasuk jenis classroom action research, menggunakan pendekatan kualitatif sebab peneliti membangun gambaran yang kompleks dan holistic, melaporkan pandangan atau opini dari kolaborator dan situasi penelitian berjalan secara yang alamiah. Penelitian diawali dengan melakukan penelitian pendahuluan dan kemudian melakukan tindakan berupa siklus, terdiri dari perencanaan, pelaksanaan tindakan, analisis data, serta refleksi. Setelah melakukan analisis dan refleksi pada siklus I, peneliti melanjutkan dengan siklus II dan setelah melakukan analisis dan refleksi hasil tindakan pada siklus II, peneliti dan kolaborator memutuskan untuk berhenti karena telah mendapatkan alur pelaksanaan JIGSAW yang ideal. Penerapan teknik pembelajaran JIGSAW dapat berlangsung sangat baik dengan teknis kunci, yaitu 1) menentukan siswa menjadi anggota kelompok ahli, 2) jumlah kelompok sesuai dengan jumlah siswa dalam kelompok ahli (tiap kelompok terdiri dari 45 siswa), 3) guru berupaya meningkatkan sikap berbahasa siswa melalui pendekatan dan komunikasi dengan baik, 4) menggunakan instrumen untuk mendeteksi sikap berbahasa siswa dan keterampilan memahami bacaan bahasa Inggris.
\end{abstract}

Kata Kunci: teknik jigsaw, sikap berbahasa, dan keterampilan memahami bacaan bahasa Inggris.

\begin{abstract}
The improved skills of understanding English reading by applying JIGSAW learning techniques are part of the effort to improve the situation and the learning process in the classroom. JIGSAW learning techniques by observing several aspects: the establishment of a discussion group, determining the number of members in a group, the number of students representing as a group of experts, and the way of evaluation to assess the effectiveness of discussions and efforts Improve student-speaking attitudes. This research includes the type of classroom action research, using a qualitative approach as researchers build complex and holistic depictions, report on the views or opinions of collaborators and research situations running naturally. Research begins by conducting preliminary research and then conducting action in the form of cycles, comprising planning, action execution, data analysis, and reflection. After conducting analysis and reflection on the I cycle, researchers proceeded with cycle II and after conducting analysis and reflection of the outcome of the action on cycle II, researchers and collaborators decided to quit as it had gained a flow of The ideal implementation of JIGSAW. The application of JIGSAW learning techniques can take place very well with the key technology that is 1) determine the students become members of the Expert Group, 2) number of groups according to the number of students in the Group of Experts (each group consists of 4-5 students), 3) Teachers To improve students ' language attitudes through well-being approaches and communication, 4) Use instruments to detect student-language attitudes and understand English reading skills.
\end{abstract}

Keywords: jigsaw techniques, language attitudes, and skills to understand English reading. 


\section{PENDAHULUAN}

Kompetensi dan performansi yang sangat penting bagi peserta didik atau siswa sesungguhnya dapat diidentifikasi, diseleksi, dibina dan dikembangkan melalui proses pendidikan yang terencana dan berkelanjutan. Satu di antara banyak upaya yang dapat dilakukan adalah melalui peningkatan kompetensi (competency) dan keterampilan (performance) membaca. Membaca menduduki posisi yang sangat penting dan paling awal bagi terbukanya pemahaman tentang berbagai konsep dalam kehidupan manusia. Melalui membaca dan pemahaman keterampilan membaca dengan benar, memungkinkan bagi seseorang untuk memperoleh pengalaman baru yang tidak dibatasi oleh ruang dan waktu. Melalui membaca, seseorang akan memperoleh berbagai informasi sesuai kebutuhan dan tujuan dari pembaca itu sendiri, di antara tujuan membaca untuk keperluan ilmu pengetahuan, teknologi, seni, dan kebudayaan.

Keterampilan membaca memiliki beberapa sub-keterampilan yang sesuai dengan tujuan membaca seperti dalam Gambar 1 berikut.

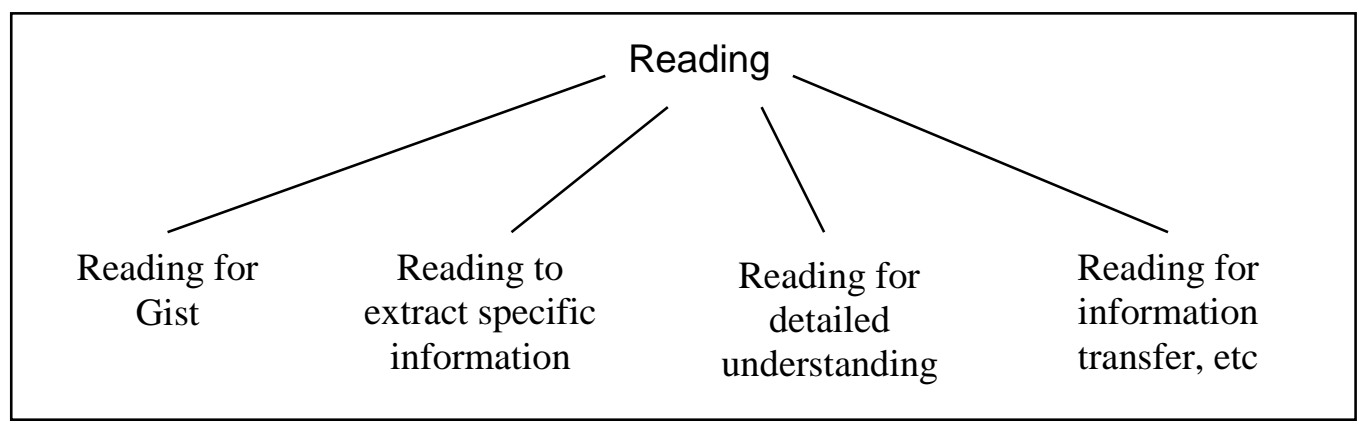

Gambar 1 Skills and Sub-skills (Reading) oleh Harmer

Pendapat Harmer (2007: 190) mengenai tujuan membaca tersebut di atas dapat dikemukakan bahwa dalam meningkatkan keterampilan memahami bacaan dalam bahasa Inggris, pembaca harus mengetahui dengan tepat alasan atau tujuannya membaca, apakah (1) membaca untuk memahami informasi umum; (2) membaca untuk memahami informasi khusus; (3) membaca untuk memahami informasi detail; dan (4) membaca untuk memahami alih informasi yang berupa simbul-simbul grafik. Dengan mengetahui alasan atau tujuannya membaca, maka pembaca akan mampu menggunakan strategi membaca yang sesuai dengan tujuannya membaca.

Keterampilan membaca siswa di satu pihak disadari masih berada dalam posisi dan strata yang belum mencapai standar. Hal ini dapat terlihat dari hasil ujian sumatif yang telah dilaksanakan di dalam kelas pada periode tahun pelajaran 2018/2019, semester ganjil yaitu sebesar 66,6 atau masih kurang terget KKM mata pelajaran bahasa Inggris di sekolah yang menjadi sasaran penelitian ini, yaitu sebesar 70,00. Kondisi dan kenyataan ini bukanlah muncul dan lahir tanpa penyebab atau kausalitas semata, melainkan semuanya memiliki penyebab baik yang bersifat internal dalam diri siswa maupun bersumber dari luar diri siswa (external sources). Faktor internal yang dapat memengaruhi semangat dan intensitas siswa dalam mengikuti pelajaran. Faktor internal yang lebih dalam adalah aspek psikologis, mencakup 1) tingkat kecerdasan/inteligensi siswa; 2) sikap siswa; 3) bakat siswa; 4) minat siswa; dan 5) motivasi siswa. Di samping hal tersebut di atas, aspek internal yang berdimensi afektif berupa kecenderungan untuk mereaksi atau merespons (response tendency) dengan cara yang relatif tetap terhadap 
objek orang, objek tertentu, seperti bacaan atau bahasa dan sebagainya, baik secara positif maupun negatif.

Penyebab dari luar diri siswa yang sangat berpotensi menyebabkan siswa mengalami kesulitan atau ketidakpahaman tentang metode dan strategi membaca adalah dari pihak pengajar (teachers aspect). Di sini guru memiliki peran sentral dan perlu memainkan perannya dengan baik sehingga memungkinkan bagi peserta didiknya memahami dan mengerti apa dan bagaimana cara memahami bacaan yang dihadapinya. Meskipun berbagai usaha telah dilakukan melalui proses pembelajaran oleh guru di sekolah. Akan tetapi, masih banyak siswa yang masih memiliki kelemahan dalam memahami isi bacaan berbahasa Inggris, terutama dalam genre akademik.

Teknik pembelajaran yang tepat tentu dapat berpengaruh terhadap keterampilan memahami bacaan bahasa Inggris. Kata pembelajaran diartikan sebagai upaya pemerolehan pengetahuan tentang suatu hal atau suatu keterampilan melalui pengalaman pengajaran (Gredler, 1991: 205). Kegiatan pengajaran merupakan bagian terintegrasi dari pembelajaran. Pembelajaran dilukiskan sebagai upaya membantu orang memeroleh perubahan melalui kegiatan pengajaran. Pengajaran membaca lebih berorientasi pada pemahaman informasi utama dari bacaan yang dihadapi, dalam hal ini bacaan bahasa Inggris, dan bukan lagi terfokus pada upaya pengalihan makna seluruh kata asing yang ada dalam bacaan. Teknik penyampaian bahan bacaan menjadi sangat penting untuk mencapai keberhasilan dan tujuan pembelajaran membaca. Teknik pembelajaran yang tepat akan memberi hasil pemahaman bacaan berbahasa Inggris yang lebih baik.

Teknik pembelajaran perlu dipahami guru agar melaksanakan pembelajaran secara efektif dalam meningkatkan hasil pembelajaran. Penerapan teknik pembelajaran harus dilakukan sesuai dengan kebutuhan siswa karena masing-masing teknik pembelajaran memiliki tujuan, prinsip, dan tekanan utama yang berbeda-beda. Menurut Joyce \& Weil (2000: 13) teknik pembelajaran adalah suatu perencanaan atau pola digunakan sebagai pedoman dalam merencanakan pembelajaran di kelas atau pembelajaran dalam tutorial dan menentukan perangkat-perangkat pembelajaran termasuk di dalamnya buku-buku, filem, computer, dan lain-lain.

Teknik pembelajaran yang berpusat dominasi guru sangat kuat melalui metode ceramah dengan siswa dalam kondisi duduk, mencatat, dan mendengarkan dan sedikit peluang bagi siswa untuk bertanya dan berdebat. Kondisi ini membuat kelas menjadi tidak kondusif karena siswa dalam keadaan pasif tidak aktif (Simamora, 2009: 57), sedangkan Akhadiah (1991-1992: 1) berpendapat pengajaran itu sendiri menurut Akhadiah merupakan proses pengubahan perilaku siswa, dari tidak tahu menjadi tahu, dari tidak mampu menjadi mampu, dari tidak terampil menjadi terampil, dan seterusnya. Dengan demikian pengajaran bahasa merupakan proses pengubahan perilaku berbahasa siswa, sehingga perlu adanya variasi guru bahasa Inggris dalam teknik pembelajaran, salah satuanya adalah teknik jigsaw.

Pembelajaran teknik jigsaw pertama sekali dikembangkan dan diujicobakan oleh Elliot Aronson dan teman-teman di Universitas Texas, kemudian diadaptasi oleh Slavin dan teman-teman di Universitas John Hopkins (Arends, 2011: 78). Teknik jigsaw dapat digunakan dalam pengajaran membaca, menulis, mendengarkan, ataupun berbicara. Dalam teknik ini, guru memperhatikan schemata atau latar belakang pengalaman siswa dan membantu siswa mengaktifkan schemata agar bahan pelajaran menjadi lebih bermakna. Selain itu, siswa bekerjasama dengan sesama siswa dalam suasana gotong royong dan mempunyai banyak kesempatan untuk mengolah informasi dan meningkatkan keterampilan berkomunikasi. 
Perlu diperhatikan dalam menggunakan teknik jigsaw untuk materi bahan belajar maka guru perlu mempersiapkan suatu tuntunan dan isi materi yang runtut serta cukup sehingga tujuan pembelajaran dapat tercapai. Berdasarkan kenyataan lapangan, dan kondisi riil yang terjadi di lapangan, penelitian ini bertujuan untuk meningkatkan keterampilan berbicara bahasa Inggris melalui teknik pembelajaran jigsaw dan memperhatikan sikap berbahasa siswa.

\section{METODE PENELITIAN}

Penelitian ini termasuk jenis penelitian tindakan kelas (classroom action research). Keutamaan dari classroom action research terletak pada adanya tindakan dalam situasi alami untuk memperbaiki atau meningkatkan proses pembelajaran serta memberi solusi dengan menjadikan guru dan siswa sebagai objek penelitian yang berada di luar orbit kehidupan mereka. Menggunakan pendekatan kualitatif, karena peneliti membangun sebuah gambaran yang kompleks dan holistik, mengalisis kata-kata, melaporkan pandangan atau opini para informan dan keseluruhan studi berlangsung dalam latar situasi yang alamiah (Wiriaatmadja, 2008: 4). Kegiatan penelitian tindakan kelas ini dilaksanakan di kelas XI IPS SMA 49 Jakarta, dengan melibatkan tiga orang kolaborator yaitu guru bahasa Inggris pada sekolah tersebut. Tugas kolaborator antara lain membantu peneliti dalam menyusun rencana tindakan dan melaksanakan observasi serta tugas yang sudah diberikan dalam rencana tindakan.

Pelaksanaan penelitian tindakan kelas ini memuat empat aspek sebagaimana pendapat Madya (2007: 58-63), yaitu 1) penyusunan rencana, 2) tindakan, 3) observasi dan evaluasi, dan 4) refleksi sebagaimana tergambarkan pada desain penelitian sebagai berikut:

\section{Skema Penelitian}

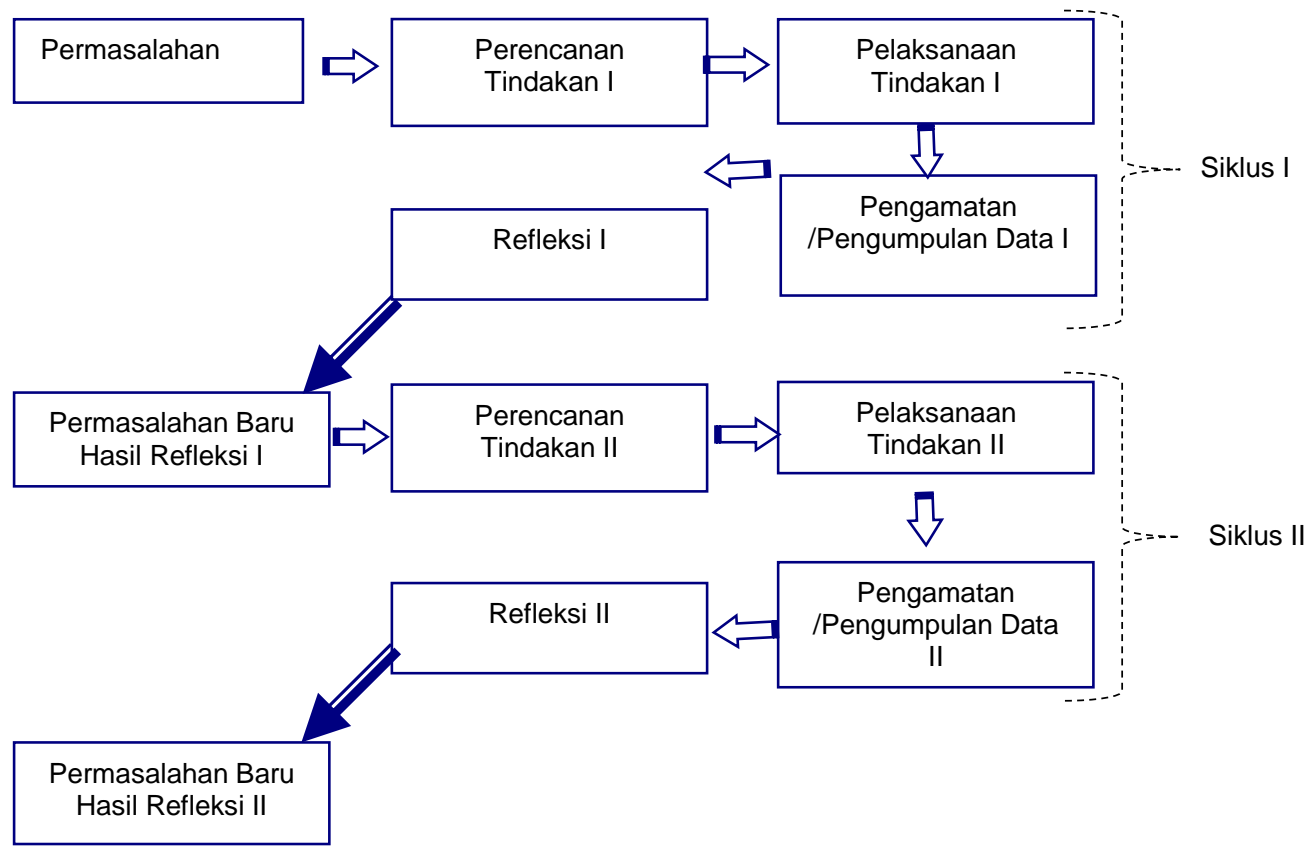

Aktivitas pada tahap persiapan yang dilakukan sebelum menjalankan kegiatan pembelajaran sebagai berikut:

1. Menyusun Rencana Program Pembelajaran (RPP). 
2. Mensosialisasikan teknik jigsaw kepada guru apabila belum menguasai penerapan pembelajaran dengan metode tersebut.

3. Membuat instrument penelitian tindakan yang terdiri dari : 1) Panduan observasi, 2) Panduan wawancara, 3) Lembar kuesioner.

Kegiatan tindakan (acting) yang dilaksanakan dalam pembelajaran menggunakan teknik jigsaw adalah sebagai berikut:

1. Guru menyampaikan pokok materi bahasa Inggris secara umum

2. Membagi kelas menjadi beberapa kelompok dan memastikan di tiap kelompok terdapat satu siswa yang dominan menguasai materi bahasa Inggris

3. Guru mengumpulkan perwakilan tiap kelompok untuk sebagai tim ahli

4. Guru memfasilitasi diskusi pada kelompok ahli

5. Setelah guru memastikan materi terserap dengan baik oleh tim ahli, meminta anggota tim ahli kembali kepada kelompok masing-masing.

Pada kegiatan analisis data yang telah direkam selama observasi dan monitoring berupa data kualitatif dan kuantitatif. Data kualitatif diperoleh dari hasil pengamatan yang dilakukan untuk mengetahui perkembangan situasi pembelajaran yang menerapkan teknik jigsaw. Pengamatan dilakukan oleh peneliti dan guru yang telah ditunjuk sebagai kolaborator. Waktu pelaksanaan pengamatan dilakukan selama pembelajaran berlangsung. Sedangkan data kuantitatif diperoleh dari hasil tes memahami teks bahasa Inggris, dan skor angket sikap berbahasa siswa terhadap kegiatan pembelajaran bahasa inggris.

Aktivitas refleksi dilaksanakan untuk mengetahui kelebihan dan kekurangan pelaksanaan tindakan. Dengan refleksi akan diperoleh masukan yang tepat untuk memperbaiki tindakan berikutnya. Adapun bahan yang akan direfleksikan berasal dari hasil observasi, hasil tes, hasil kuesioner dan hasil wawancara selama pelaksanaan tindakan. Instrumen yang digunakan dalam penelitian ini antara lain: 1) Angket untuk mengukur sikap berbahasa siswa dan 2) Instrumen Tes untuk mengetahui keterampilan memahami bacaan bahasa Inggris siswa, berupa tes tertulis berjenis pilihan ganda. Kedua instrumen tersebut telah teruji dengan baik berupa uji validitas dan reliabilitas. Sesuai pendapat Brown (2000: 117) penilaian yang dilakukan guru terhadap siswanya dimaksudkan untuk membantu mereka belajar bahasa, membantu mereka meningkatkan pembelajaran melalui penilaian diagnostik, atau tes hasil belajar.

Tahapan Penelitian Tindakan

\section{Siklus 1}

\section{Perencanaan}

a. Menyusun rencana pembelajaran bahasa Inggris dengan materi pokok dengan menerapkan teknik pembelajaran Jigsaw.

b. Mensosialisasikan teknik pembelajaran Jigsaw kepada kolaborator apabila belum menguasai penerapan pembelajaran dengan metode tersebut.

c. Membuat instrument penelitian tindakan yang terdiri dari : 1) Panduan observasi, 2) Panduan Wawancara 3) Lembar catatan lapangan, 4) Angket Motivasi Belajar, dan 5) Tes Penilaian

\section{Tahap Pelaksanaan}

a. Guru menjelaskan skenario pembelajaran.

b. Guru menyajikan materi pokok pelajaran bahasa Inggris.

c. Siswa dibagi ke dalam 8 kelompok yang terdiri dari maksimal 5 siswa. 
d. Guru memastikan tiap kelompok telah terisi dengan satu siswa dengan kemampuan bahasa Inggris paling dominan.

e. Guru mengumpulkan 5 siswa yang telah menguasai materi sebagai anggota tim ahli.

f. Sekitar 10 menit anggota tim ahli yang terdiri dari 5 siswa diminta untuk memperdalam menguasai materi dengan baik.

g. Setelah guru memfasilitasi dan menyakini tim ahli benar-benar menguasai materi, maka maka meminta anggota tim ahli kembali ke kelompok asal untuk menyiapkan materi.

h. Sementara guru terus memantau aktivitas diskusi pada tiap kelompok

i. Kemudian dilanjutkan diskusi kelas yang dipimpin guru untuk memastikan materi telah tersampaikan yaitu dengan beberapa pertanyaan secara terbuka kepada tiap kelompok.

j. Penutup

3. Tahap observasi dan analisis

a. Pengamatan terhadap pelaksanaan teknik pembelajaran Jigsaw.

b. Pengamatan terhadap kegiatan guru dalam pembelajaran bahasa Inggris yang menggunakan teknik pembelajaran Jigsaw.

c. Pengamatan terhadap sikap berbahasa siswa dalam kegiatan pembelajaran dikelas.

d. Pengamatan dilakukan oleh peneliti dan guru yang diajak bekerjasama sebagai kolaborator selama tindakan pembelajaran bersangsung.

e. Pengamatan dilakukan dengan observasi dan wawancara secara langsung pada kolaborator dan siswa.

f. Analisis dilakukan terhadap data hasil observasi dan wawancara selama pelaksanaan siklus pembelajaran.

4. Tahap Refleksi

a. Evaluasi terhadap pelaksanaan tindakan untuk mengetahui hasil belajar siswa setelah mengikuti pelajaran bahasa Inggris dengan menggunakan teknik pembelajaran Jigsaw.

b. Melakukan pertemuan antara peneliti, observer dan guru kolaborator untuk membahas hasil evaluasi pelaksanaan tindakan.

c. Memperbaiki pelaksanaan tindakan sesuai hasil triangulasi data, untuk digunakan pada siklus berikutnya.

1. Perencanaan

a. Identifikasi masalah dan alternatif pemecahan

b. Pengembangan program tindakan II

2. Tindakan Pelaksanaan program tindakan II

3. Pengamatan dan analisis

4. Refleksi

Pengumpulan data dan analisis tindakan II

Evaluasi tindakan II

Sehingga peran peneliti dalam hal ini adalah sebagai pemimpin penelitian, melaksanakan peran sebagai pembuat rencana tindakan, melaksanakan rencana tahapan tindakan, mengawasi pelaksanaan rencana tahapan tindakan, dan memastikan segala tindakan yang dilakukan sesuai dengan rencana tahapan tindakan.

\section{HASIL DAN PEMBAHASAN}

Keterampilan memahami bacaan bahasa Inggris siswa terbukti mengalami peningkatan setelah menerapkan teknik pembelajaran jigsaw. Hasil penelitian menunjukkan bahwa dalam memahami bacaan bahasa Inggris terutama dalam genre pengetahuan siswa harus dibantu dalam kelompok diskusi yang dipimpin oleh siswa yang memiliki kemampuan sangat baik. Prinsip saling mempelajarkan antara siswa dalam dalam kelompok diskusi kecil tersebut menjadi media untuk mengasah keterampilan memahami bacaan bahasa Inggris. Dalam penelitian ini melalui efektivitas pelaksanaan teknik pembelajaran menggunakan jigsaw dan terus mengoptimalkan sikap berbahasa siswa. 
Dalam pengajaran membaca dengan menggunakan teknik jigsaw, siswa dibiasakan untuk mengaktifkan atau mengembangkan pemahaman mereka tentang ideide pokok dan ide-ide pendukung dari teks yang dibaca. Siswa diminta untuk mendiskusikan tema inti teks dengan cara mengaitkan ide pokok teks dengan segala sesuatu yang berkaitan dengan tema, yang telah mereka kuasai sebelumnya. Cara ini tentu saja dapat membantu siswa dalam mengembangkan jaringan pemahamannya, sehingga ketika dihadapkan pada teks, siswa dapat membuat simpulan-simpulan atau dugaandugaan sementara tentang tema teks yang akan dibaca secara luas dan menyeluruh. Melalui teknik Jigsaw yaitu sistem saling membelajarkan dalam kelompok, siswa dalam kelompok mendapatkan penguatan pemahaman dari sesama siswa yang memiliki kemampuan lebih cepat menangkap materi bahasa Inggris.

Ketika dibandingkan dengan penggunaan teknik pengajaran konvensional, siswa diajarkan melalui pembelajaran di mana siswa berhadapan langsung dengan teks dan ketika mereka menemui kata-kata asing yang tidak dipahami, mereka diminta untuk mengingat makna kata tersebut dengan merujuk pada kata asing yang mirip yang pernah dikuasai, gambar dan petunjuk lainnya. Dengan cara ini, siswa tidak dilatih untuk mengembangkan pemahaman mereka secara menyeluruh tentang tema teks, namun mereka dibiasakan mengartikan setiap kata asing, yang bisa saja terlepas dari konteks tema. Cara seperti ini tentu saja menghasilkan pemahaman yang bersifat harfiah dan bukan kontekstual.

Berkenaan dengan kondisi tersebut di atas, Arends (2011: 78) mengatakan bahwa pembelajaran yang menggunakan teknik jigsaw merupakan teknik pembelajaran kooperatif di mana siswa belajar dalam kelompok kecil yang terdiri dari 4-6 orang secara heterogen dan bekerja sama saling kebergantungan yang positif dan bertanggung jawab ketuntasan bagian materi pelajaran yang harus dipelajari dan menyampaikan materi tersebut kepada anggota kelompok yang lain. Kemudian Lie (2012: 67-73) menambahkan bahwa pembelajaran teknik jigsaw didesain untuk meningkatkan rasa tanggung jawab siswa terhadap pembelajarannya sendiri dan juga pembelajaran orang lain. Siswa tidak hanya mempelajari materi yang diberikan, tetapi mereka juga harus siap memberikan dan mengajarkan materi tersebut pada anggota kelompoknya yang lain. Dengan demikian, "siswa saling bergantung satu dengan yang lain dan harus bekerja sama secara kooperatif untuk mempelajari materi yang ditugaskan".

Selanjutnya disadari bahwa adanya perbedaan hasil yang signifikan antara siswa yang belajar dengan teknik jigsaw dan konvensional dapat dipahami karena pembelajaran menggunakan teknik jigsaw menunjukkan hasil lebih baik sebagaimana dikemukakan oleh Roymond (2009: 57), bahwa sebab dalam proses pembelajaran menggunakan teknik konvensional cenderung berpusat pada guru dan mengutamakan pencapaian target materi kurikulum, mementingkan penghafalan konsep bukan pada isi bacaan. Dominasi guru sangat kuat melalui metode ceramah dengan siswa dalam kondisi duduk, mencatat, dan mendengarkan dan sedikit peluang bagi siswa untuk bertanya dan berdebat. Kondisi ini membuat kelas menjadi tidak kondusif karena siswa dalam keadaan pasif tidak aktif.

Berkaitan dengan optimalisasi sikap berbahasa siswa Anderson (dalam Chaer, 2004) mengemukakan orang yang memiliki sikap positif terhadap suatu bahasa yang dipelajari akan memberi dampak positif terhadap apa yang dipelajarinya, seperti dalam mempelajari bahasa Inggris. Allan (2001: 303) mengatakan bahwa sikap adalah suatu kecenderungan untuk merespon secara positif atau negatif terhadap objek, situasi, institusi, atau orang tertentu. Orang yang memiliki sikap positif menurut Gravin \& Mathiot (dalam Chaer 2004: 152) setidaknya memiliki tiga ciri, di antaranya: (1) 
Kesetiaan bahasa (language royalty) yang mendorong masyarakat suatu bahasa mempertahankan bahasanya dan apabila perlu mencegah adanya pengaruh bahasa lain; (2) Kebanggaan bahasa (language pride) yang mendorong orang mengembangkan bahasanya dan menggunakannya sebagai lambang identitas dan kesatuan masyarakat; dan (3) Kesadaran adanya norma bahasa (awareness of the norm) yang mendorong orang menggunakan bahasanya dengan cermat dan santun, dan merupakan faktor yang sangat besar pengaruhnya terhadap perbuatan yaitu kegiatan menggunakan bahasa (langue use).

Sehingga sikap positif terhadap bahasa yang sedang dipelajari ditunjukkan dengan adanya kecenderungan untuk berpikir, merasakan dan berperilaku terhadap bahasa yang dipelajari, seperti sikap siswa terhadap bahasa Inggris, khususnya terhadap keterampilan berbicara bahasa Inggris yang mencakup ketepatan kosakata, tata bahasa, intonasi, kelancaran berbicara serta relevansi dengan topik pembicaraan.

Hasil penerapan tindakan kelas menunjukkan bahwa teknik pembelajaran jigsaw dan bersikap positif dalam mempelajari suatu bahasa, khususnya bahasa Inggris akan memberi kontribusi positif. Hal tersebut dapat terjadi, karena memiliki sikap negatif pada suatu bahasa yang sedang dipelajari akan memberi dampak negatif atau sulit menguasainya baik secara kompetensi maupun performansi, seperti bahasa Inggris. Berkenaan dengan sikap negatif, Anderson (dalam Chaer, 2004) mengemukakan bahwa sikap negatif terhadap suatu bahasa ditandai dengan menghilang atau melemahnya perhatian dari diri seseorang atau dari diri sekelompok orang anggota masyarakat tutur suatu bahasa berarti telah melanda diri orang atau sekelompok orang itu. Lebih lanjut Anderson dalam Chaer (2004: 152) mengatakan bahwa faktor yang bisa menyebabkan hilangnya rasa bangga terhadap bahasa sendiri dan menumbuhkan pada bahasa lain, antara lain faktor politik, ras, etnis, gengsi dan sebagainya.

Sementara itu, hasil pengamatan oleh kolaborator melaporkan bahwa bagi siswa yang awalnya memiliki sikap berbahasa negatif setelah mengikuti pelaksanaan pembelajaran bahasa Inggris dengan teknik jigsaw menjadi lebih aktif atau bersikap bahasa lebih baik.

Secara teoretis terbukti benar bahwa orang yang memiliki sikap negatif dan belajar dengan metode konvensional dapat memiliki kompetensi dan keterampilan membaca bahasa Inggris namun tidak optimal. Dalam perkataan lain, tidak hanya siswa yang memiliki sikap positif dan diajarkan dengan teknik jigsaw saja yang dapat mencapai keterampilan membaca, akan tetapi siswa yang memiliki sikap negatif dan diajarkan teknik konvensional pun memiliki keterampilan memahami bacaan bahasa Inggris, tetapi rendah.

Sementara argumentasi atau asumsi yang dapat dikemukakan berkaitan dengan pembelajaran menggunakan teknik konvensional tidak seutuhnya kurang/tidak memberi kontribusi positif dalam mendukung pemahaman atau penguasaan materi ajar yang disampaikan guru, terutama dalam pembelajaran bahasa Inggris, sebab sangat mungkin terjadi pada siswa/orang-orang tertentu dapat menerima pelajaran dengan baik dengan metode konvensional, meskipun di lain pihak tidak sedikit siswa/orang lain sulit menerima atau memahami materi ajar jika diajarkan dengan teknik konvensional. Hal ini diduga karena pada dasarnya setiap orang/siswa memiliki pola dan cara tersendiri dalam memahami apa yang sedang dipelajarinya.

Secara keseluruhan implementasi teknik pembelajaran jigsaw memiliki pengaruh positif terhadap sikap berbahasa siswa, kemudian secara langsung mampu meningkatkan keterampilan memahami teks bahasa Inggris sehingga hendaknya guru dalam kelas pembelajaran bahasa Inggris dapat menerapkan teknik pembelajaran jigsaw ketika ingin 
meningkatkan keterampilan memahami bacaan bahasa Inggris siswa. Di samping itu guru juga harus menggunakan instrumen dan kepekaan secara intuisi menentukan siswa yang memiliki kemampuan lebih dibanding teman dalam kelas untuk dikumpulkan sebagai kelompok ahli, juga dapat menentukan sekelompok siswa yang masuk kelompok ahli memiliki sikap berbahasa yang sangat baik.

\section{SIMPULAN}

Berdasarkan hasil penelitian yang dikemukakan sebelumnya dapat ditarik simpulan, yaitu (1) Hasil temuan menunjukkan bahwa teknik pembelajaran jigsaw mampu meningkatkan keterampilan memahami bacaan bahasa Inggris; (2) Teknik pembelajaran jigsaw mampu berkolaborasi secara optimal ketika guru terus meningkatkan sikap berbahasa Inggris siswa. Perlakuan pada kelompok siswa yang memiliki sikap berbahasa positif yang belajar dengan teknik jigsaw mendapatkan hasil keterampilan memahami bacaan bahasa Inggris yang cepat daripada siswa yang memiliki sikap berbahasa negatif, (3) Implementasi teknik pembelajaran Jigsaw yang menjadi temuan pada peneliti ini, yaitu sebaiknya waktu penyampian pokok materi secara umum kepada semua siswa yang paling tepat adalah setelah dibentuknya kelompok diskusi yang terdiri dari 4-5 siswa dan telah dipisahkannya anggota tim ahli bahasa Inggris siswa, (4) Pentingnya memperhatikan sikap berbahasa bahasa Inggris sebagai faktor pendukung utama peningkatan keterampilan membaca bacaan bahasa Inggris.

\section{DAFTAR PUSTAKA}

Akhadiah, S. (1991-1992). Bahasa Indonesia III (Jakarta: Departemen Pendidikan dan Kebudayaan, Ditjen Dikti Proyek Pembinaan Tenaga Kependidikan.

Ailan, L. R. (2001). Psycological testing and assesment. Massachusetts: Allin and Bacon.

Arends, R. (2011). Learning to teach. USA: McGraw-Hill Humanities/Social Sciences/Languages.

Brown, H. D. (2000). Teaching by principles: An interactive approach to language pedagogy. Second Edition. New Jersey: Prentice all Regents.

Chaer, A. \& Agustina. (2004). Sosiolinguistik. Jakarta: Rineka Cipta.

Daise, D., Norloff, C., \& Carne, P. (2011). Skills for success reading and writing 4. USA: Oxford University Press.

Gredler, M. E. B. (1991). Belajar dan membelajarkan. Terjemahan Munandir. Jakarta: PT Raja.

Harmer, J. (2007). The practice of english language taeching: longman handbool for language teachers. 4 Edition. UK: Longman Group UK Limited.

Joyce, B. \& Weil, M. (2000). Models of teaching. Boston: Allyn and Bacon.

Lie, A. (2012). Cooperative learning. Yogyakarta: Jinda Pena publisher. 
Madya, S. (2007). Teori dan praktek penelitian tindakan. Bandung: Alfabeta.

Miller, D. (2006). Developing reading skills, A practical guide to reading comprehension excercises. Portland, Maine: Stenhouse Publishers.

Simamora, R. H. (2009). Buku ajar pendidikan dalam keperawatan. Jakarta: EGC.

Triandis, H. E. (2008). Attitude and attitude change. New York: Taylor \& Francis Group, LLC.

Wiriaatmadja, R. (2008). Metode penelitian tindakan kelas. Bandung: PT. Remaja Rosdakarya. 